Silvia Contarini, Claire Joubert and Jean-Marc Moura, eds. Penser la différence culturelle du colonial au mondial : une anthologie transculturelle.

\title{
Alexandra Reza
}

\section{CpenEdition}

\section{Journals}

Electronic version

URL: https://journals.openedition.org/ces/2118

DOI: $10.4000 /$ ces. 2118

ISSN: 2534-6695

Publisher

SEPC (Société d'études des pays du Commonwealth)

Electronic reference

Alexandra Reza, "Silvia Contarini, Claire Joubert and Jean-Marc Moura, eds. Penser la différence culturelle du colonial au mondial : une anthologie transculturelle.", Commonwealth Essays and Studies [Online], 42.2 | 2020, Online since 30 September 2020, connection on 18 January 2022. URL: http:// journals.openedition.org/ces/2118; DOl: https://doi.org/10.4000/ces.2118

This text was automatically generated on 18 January 2022

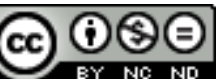

Commonwealth Essays and Studies is licensed under a Licence Creative Commons Attribution - Pas d'Utilisation Commerciale - Pas de Modification 4.0 International. 


\title{
Silvia Contarini, Claire Joubert and Jean-Marc Moura, eds. Penser la différence culturelle du colonial au mondial : une anthologie transculturelle.
}

\author{
Alexandra Reza
}

\section{REFERENCES}

Paris: Éditions Mimésis. 473 p. ISBN: 978886976 1546. €29.00.

1 This is an anthology of 71 texts originally written in English, French, German, Spanish, Italian, and Portuguese, translated into French and juxtaposed to illuminate the constitutively "multinational and co-colonial" (19) dimensions of colonialism. Each of the six subsections, differentiated by language, has a separate editor, though we are invited to read across the divisions to understand histories of European colonialism as connected, and to see the echoes as well as silences that characterise the thinking and writing about colonialism in different time-spaces. In this volume, familiar figures of the anti- and postcolonial canon are conjugated in productive comparison with less well-known thinkers. A transcultural reading, the editors argue, can bring forward the intimate relation between culture and politics which organises modernity and its geopolitics (22).

2 This book is the latest intervention by postcolonialist scholars working in languages other than English to challenge both the predominantly anglophone terms of debates in postcolonial studies and the linguistic/national fragmentation of work on empires and their afterlives. Prominent voices in "postcolonial francophone studies" have repeatedly called for a comparatist sensibility over the last decade, notably charles 
Forsdick and David Murphy. In France, Claire Joubert's 2014 edited collection Le Postcolonial comparé was a major intervention. Her co-editor here, Jean-Marc Moura, is a key protagonist in the institutionalisation of postcolonial studies in France. His 2014 collection Interprétations postcoloniales et mondialisation also took a multilingual approach. In assembling a transcultural collection of primary texts with an emphasis on anti-colonial thinking, this latest volume is a welcome step forward towards a more multilingual and comparative approach to the postcolonial, which will be of great benefit to French-language readers.

3 The particular strengths of the collection lie in bringing forward new thinkers and juxtapositions. The English- and French-language sections are particularly successful in giving space to unexpected combinations of writers, avoiding the temptation to genuflect to canonical texts. Alongside self-consciously "theoretical" writing we find autobiography, testimony, interviews. The edition is particularly attuned to the linguistic and cultural but importantly includes critiques of colonial capitalism, crucial to understanding current dynamics of neo-liberal neo-colonialism. It is productive, for instance, to have Guevara's call for an actual dismantling of the international competitive economy laid out next to discussions of the discursive repercussions of coloniality. The italophone section importantly situates the Mediterranean as a space of labour and as a key site of contestation for contemporary questions of the European colonial, bound up with work and migration.

Indeed, these translated essays turn our attention to important spaces which enrich our understanding of the multi-scalar conjuncture of colonialism: Gramsci's discussion of the Italian south, or Margarida Calafate Ribeiro's discussion of post-dictatorship Portugal. The Fijian writer Epeli Hau'ofa's essay "Our Sea of Islands" puts us in mind of other island-writers across the colonial scene, of the "arched archipelago" of Aimé Césaire's Cahier and of the lusophone poet Manuela Margarido's islands of São Tomé e Príncipe.

Inevitably an anthology like this can only sketch some pistes. Some inconsistencies niggle: why is the francophone section longer than any of the other sections? Why does the range of dates differ with each section? (Confusingly, the French and English sections start after WW2; the German section begins with Goethe; the Portuguese section begins in 1453.) How have these six languages been chosen as the "first circle" of colonial languages? (A somewhat throwaway comment in the introduction seems to me insufficient explanation for excluding Dutch, for example). A more developed sense of the basis and criteria for selection would have been useful. Additionally, more historical and contextual introductions would have helped situate these sometimes extremely telegraphic selections in the broader works from which they have been excerpted, and in space and time, not just in language. Frantz Fanon does not have the same institutional genealogy as university professor Walter Mignolo. There are missed opportunities, too: that the hispanophone section includes no women or theorists of gender means the interrogations of colonial-capitalist patriarchy set out in other sections appear in this collection to be missing from hispanophone thinking, when in fact figures such as María Lugones, Raquel Gutiérrez, and Silvia Rivera Cusicanqui have been markedly creative in this regard. At times, the form of the anthology - which separates texts by linguistic field - risks ossifying the separations between different language histories, rather than drawing attention to overlaps between them. 
6 Yet, in encouraging us to read across the volume's sections, the editors invite us to walk even further down the path they have started upon. Many of the essays themselves sit uneasily in the volume's linguistically-defined framework. The Gikuyu writer Ngũgĩ wa Thiong'o, whose co-written "On the Abolition of the English Department" opens the anglophone section, is well-known for his (at best) ambivalent relationship to the "anglophone." Mário Pinto de Andrade's piece in the lusophone section was originally written and published in French. Alioune Diop's essay that opens the francophone section could have been included in the anglophone section given that it was also published in English in the same 1947 edition of Présence Africaine in which the French essay appeared. For Helena Carvalhão Buescu, in the lusophone section, "my perspective and my angle of observation [...] are not, strictu sensu, lusophone" (456). In this sense, the anthology's most powerful critical charge lies in the direction towards which it points. That is, towards comparative postcolonial work that can reckon with the translated and connected histories of imperialism and anti-imperialism in different contexts, and that can shrug off the old colonial fiction of hermetic language worlds - a fiction whose vestiges Contarini, Joubert and Moura rightly and ambitiously set out to reject.

\section{AUTHORS}

\section{ALEXANDRA REZA}

Dr. Alexandra Reza is a Junior Research Fellow in French at Trinity College, Oxford University. Her research lies at the intersection of comparative literature, postcolonial studies and political thought, and focuses on twentieth-century writing, filmmaking and broadcasting in French, Portuguese and English. In particular, she investigates how anti-colonial histories of thinking about comparison, form, aesthetics, political community and geography can intervene in current debates in literary studies. 